\title{
Towards a theory of critical energy literacy: the Youth Strike for Climate, renewable energy and beyond
}

\author{
Gregory Lowan-Trudeau ${ }^{1, \star}$ and Teresa Anne Fowler ${ }^{2}$ \\ ${ }^{1}$ University of Calgary, Werklund School of Education, Calgary, Canada CA and ${ }^{2}$ Concordia University of Edmonton, \\ Department of Physical Education \& Wellness, Faculty of Education, Edmonton, Canada CA \\ ${ }^{*}$ Corresponding author. E-mail: gelowan@ucalgary.ca
}

(Received 05 February 2021; revised 23 July 2021; accepted 27 July 2021; first published online 13 September 2021)

\begin{abstract}
The Youth Strike for Climate raised important global attention to interconnected climate, energy and environmental issues - it also compelled us to consider what we will do to address these pressing challenges. Developed through consideration of such dynamics, we propose critical energy literacy as an emerging theory that denotes understanding of the social, environmental, political and economic challenges, benefits and impacts of various energy sources, developments and technologies. Critical energy literacy is grounded in critical and decolonising approaches to STEM education; considerations for collaborative multi-, interand Trans disciplinary pedagogy; critical place-based inquiry and pedagogy; critical gender perspectives and critical media literacy and engagement. Enhancing societal critical energy literacy will assist with more equitable energy, transit, construction and environmental planning by and for communities, businesses and governments. In this theory-building commentary, we share insights related to and principles for our emerging theory of critical energy literacy which coalesced through personal experience with and previous studies into related initiatives and areas of inquiry, and recent reviews of literature as well as $\mathrm{K}-12$, post-secondary and not-for-profit curricula in Canada with consideration for international contexts. A discussion of renewable energy development and education focused on the Canadian province of Alberta is presented as an illuminating exemplar.
\end{abstract}

\section{Introduction}

The Youth Strike for Climate brought important global attention to interconnected climate, energy and environmental issues. Inherent within considerations of climate change are the role of energy production, capture, consumption and related policies - highly technocratic areas of consideration. Youth in many areas of the world are more electronically connected and able to independently access climate change related and other environmental information via the internet and other sources than ever before. However, given the overwhelming volume of information currently available and the lack of regular access for some socioeconomically or otherwise marginalised youth to digital and/or non-digital learning resources, finding reliable sources of information regarding climate change, energy and environmental topics while making sense of associated dynamics are daunting challenges for the best of educators and most critically informed youth. As such, we propose that collaborative approaches to critical energy literacy between educators and learners in various community, school and post-secondary contexts will prove beneficial and supportive for youth engaging in related activism and advocacy.

\footnotetext{
*The online version of this article has been updated since original publication. A notice detailing the change has also been published

(C) The Author(s), 2021. Published by Cambridge University Press. This is an Open Access article, distributed under the terms of the Creative Commons Attribution-NonCommercial-NoDerivatives licence (http://creativecommons.org/licenses/by-nc-nd/4.0/), which permits non-commercial re-use, distribution, and reproduction in any medium, provided the original work is unaltered and is properly cited. The written permission of Cambridge University Press must be obtained for commercial re-use or in order to create a derivative work.
} 
The Youth Strike for Climate ${ }^{1}$ was a series of interconnected and iteratively inspired activist initiatives around the world that typically involved school aged youth (and other supporters) attending climate-related events, rather than school, on Fridays. The Youth Strike for Climate was initiated by Greta Thunberg, a Swedish secondary school student, in 2018, reached a peak of activities in 2019 and continues to inform related events and organisations today (e.g., see https://globalclimatestrike.net).

In addition to providing a platform for raising global awareness of climate change and other related environmental issues, the Youth Strike for Climate revealed ongoing intersectional prejudices and injustices. For example, explicit and implicit gender violence was expressed by oil and gas industry advocates who created misogynistic imagery and discourse related to Greta Thunberg, founder of the Youth Strike for Climate, in an attempt to discredit the movement (CBC News, 2020). Such manifestations further emphasise well-established historical and contemporary links between extractive resource industries and gendered violence against Indigenous women and girls, in particular, in Canada (Awasis, 2014), Australia (Carrington et al., 2010), the United States (Lucchesi, 2019; Weber, 2014) and elsewhere. However, Indigenous women such as Winona LaDuke (2014) have also risen to become prominent leaders in the climate movement, community-based renewable energy development and related socioecological advocacy and activism.

We approach this theory-building commentary as university-based scholar educators in the Canadian province of Alberta, a well-known controversial centre of oil and gas extraction (Katz-Rosene, 2017), and promising context for renewable energy production (Kralovic \& Mutysheva, 2006). This work grows out of previous activist initiatives and related research (Lowan-Trudeau, 2019; Lowan-Trudeau \& Fowler, in press). Our sense from having participated in and/or supported the Youth Strike for Climate and other similar initiatives is that leaders and participants alike are building and expressing notable critical energy literacy while thinking about what's next after/as a result of such activist initiatives. Associated questions arise such as, "What are we protesting not only against, but also towards? And how can we facilitate positive and critically informed long-term change?" In the following, we present critical energy literacy as one possible component of a solutions-oriented approach. We define critical energy literacy as an understanding of the social, environmental, political and economic challenges, benefits and impacts of various energy sources, developments and technologies.

\section{Energy Literacy}

Common definitions of energy literacy in both scholarly and government documents acknowledge the scientific, social and/or political aspects germane to understanding energy technologies and systems (e.g., Martins et al., 2020; U.S. Department of Energy, 2017). In our review of energy literacy literature, we also encountered behavioural approaches to energy literacy aimed at encouraging pro-environmental actions as a result of enhanced energy literacy (e.g., DeWaters \& Powers, 2011). However, overtly critical energy perspectives that explicitly recognise interrelated societal and environmental inequities are somewhat elusive (Delgado, 2016).

For example, in a review of Canadian provincial and territorial curricula focused on critical and Indigenous environmental issues, we found that explicitly critical approaches to energy-related topics were notably lacking in most regions (Lowan-Trudeau \& Fowler, in press). In a subsequent review of non-profit educational and post-secondary program descriptions and curricula, we found that, while more overtly critical energy perspectives that bring together the social, political and technical aspects of energy literacy are emerging in some programmes and organisations (e.g., see Carleton University's Sustainable Energy graduate programs: https:/carleton.ca/cserc/ academic-programs/graduate-programs-in-sustainable-energy/), many still take a primarily technical/scientific approach. As such, this is an outstanding issue in the field with the potential for 
significant growth and transformation as has been persistently noted by energy education scholars (Jennings, 2009).

Moreover, we found that energy education programmes developed by independent non-profit groups such as the Toronto Renewable Energy Co-Operative (TREC; www.trec.on.ca), an organisation that facilitates community-based renewable energy developments, often present more critical energy perspectives and intersectional voices reflective of environmental justice (Pellow, 2017), just sustainability (Agyeman, 2008) and just transition (Newell \& Mulvaney, 2013) paradigms than those that are closely affiliated with and/or funded by governments or the oil and gas industry. For example, Inside Education, a natural resource and environmentally oriented non-profit educational organisation in the province of Alberta - Canada's oil and gas industry hub - lists both the Government of Alberta, a predominantly conservative and pro-fossil fuel entity and several oil and gas corporations, among others, as "partners" on their website (see https://www. insideeducation.ca/partners/). Unsurprisingly, much of the energy related information that is shared as a potential resource for teachers and students presents a neutral or even supportive perspective on, for example, Alberta's infamous oil/tar sands (e.g., https://www.insideeducation.ca/learningresources/classroom-learning-resources/elementary-school/\#oil-sands-field-trips). These iterative insights led us to discuss and consider possibilities for more critical approaches to energy literacy.

\section{Critical Energy Literacy}

In consideration of the trends and dynamics described above, we propose critical energy literacy as an emerging theory that denotes critical understanding of the social, environmental, political and economic challenges, benefits and impacts of various energy sources, transportation technologies and construction technologies including, but not limited to wind, solar, passive, small- or largescale hydro, tidal, geothermal, oil and gas, coal and nuclear. As a theory, critical energy literacy will assist with the articulation and exploration of the relationships between interrelated phenomena (Anfara \& Mertz, 2006).

Similar to related concepts with roots in critical theory such as critical media literacy (Kellner \& Share, 2007; Robertson \& Scheidler-Benns, 2016), critical energy literacy leads us to not only identify but also to challenge and strive to address intersectional inequities in society. For example, adopting a critical energy lens may assist in identifying the past, present or projected socioenvironmental impacts of or benefits for a marginalised community in relation to a given energy project. As such, critical energy literacy is resonant with, but distinguished from, similar concepts such as critical environmental justice (Pellow, 2017) and just sustainability (Agyeman, 2008) by its specific focus on energy.

Facilitating critical energy literacy may prove challenging for educators at various levels in a range of contexts (K-12, post-secondary, community) tasked with fostering such understanding for their students, as they themselves may be more versed in certain areas of energy literacy than others (e.g., scientific/technical vs. social). In response, a small, but increasing number of educational resources and programmess for educators, grassroots community organisers and professionals working in science and/or policy settings have been developed to promote more comprehensive understanding of energy sources, challenges and possibilities.

\section{Emerging principles of critical energy literacy}

Reflective of the aforementioned dynamics and influences, critical energy literacy is theoretically framed by scholarship in the areas of critical and decolonising science, technology, engineering and mathematics (STEM) education; considerations for collaborative multi-, inter- and transdisciplinary pedagogy; critical place-based inquiry and pedagogy; critical gender perspectives and critical media literacy and engagement. 


\section{Critical approaches to STEM}

Building on the foundational work of scholars such as Aikenhead and Ogawa (2007) and Barnhardt and Kawagley (2005), the growing field of critical STEM education provides key insights for critical energy literacy. For example, Bullock (2017) rightly asks whether prioritising universal STEM education is indeed a remedy for socioeconomic disparity or simply a tool to further reinforce societal hierarchies. Indigenous and non-Indigenous scholars alike are also considering the colonial connotations of conventional STEM research and education as well as alternative, decolonised paths forward (Bang \& Medin, 2010; Lowan-Trudeau, 2017). They also exhort educators and researchers to deeply consider the interconnection of critical social, environmental and technological phenomena (de Freitas et al., 2017).

\section{Collaborative approaches}

Important questions also arise in both educational and research contexts when considering how to best bring together disparate bodies of knowledge through multi-, inter- and transdisciplinary approaches (Bernstein, 2015; Choi \& Pak, 2006). Reflective of similar models of cultural interaction such as multi, inter and transculturalism (Welsch, 1999), multi- and interdisciplinary approaches are based on the maintenance of disciplinary boundaries - multidisciplinary approaches promote sharing between knowledge systems for mutual consideration while interdisciplinary approaches go further to seek possible points of convergence or integration, but not hybridity (Lowan-Trudeau, 2015). Transdisciplinary approaches transcend disciplinary boundaries to create new hybrids that incorporate tailored elements from traditional fields (Bernstein, 2015; Reid et al., 2017). While multi- and interdisciplinary pedagogical approaches incorporate the breadth of knowledge of collaborating educators and their associated knowledge systems, transdisciplinary approaches require individual educators to acquire and foster focused depth of understanding by bringing together discrete fields in relation to a complex topic. As such, with consideration for the dynamics described above and in light of the experiences of those who have made initial attempts in the area of critical energy education (e.g., Henderson, 2014), a specific consideration for critical energy literacy is whether it is better to promote multi- or interdisciplinary collaboration between individual educators from discrete subject areas or to develop pre- and in-service training opportunities for a new group of individuals capable of serving as transdisciplinary energy educators. However, a dichotomous approach of this nature may be inappropriate with a more balanced solution lying somewhere along a multi-inter-transdisciplinary continuum.

\section{Context and place}

Considering the role of context and place in pedagogy and inquiry is also central to critical energy literacy. Greenwood's (formerly Gruenewald) (2003) early conception of a critical pedagogy of place exhorts educators to deeply consider their sociocultural, geographical and ecological contexts through concepts such as decolonisation and re-inhabitation while facilitating similarly critical consciousness for their students. Greenwood's work has led to numerous responses, heated debate and a substantial amount of iterative scholarship that further incorporates concepts such as reconciliation (Bowers, 2008; Greenwood, 2008; Lowan-Trudeau, 2017; Scully, 2012; Stevenson, 2008). Tuck and McKenzie (2015) also critically consider place and encourage researchers to directly acknowledge and incorporate place and context in our work in connection with socioecological relationships and Indigenous topics in particular.

\section{Critically considering and engaging with media}

The central role of popular, social and digital media upon our collective awareness and understanding of various energy technologies (Brady \& Monani, 2012; Hodges \& Stocking, 2016; Walker \& Christidis, 2018) is a salient consideration for critical energy literacy. As critical media 
literacy and environmental communication scholars emphasise, popular media in particular not only influences us - it may also explicitly and implicitly express the beliefs and perspectives of the journalist, publisher and/or broader societal context (Kellner \& Share, 2007; Milstein et al., 2017; Takahashi \& Rosenthal, 2018). Moreover, critical assessment of environmentally related media also reveals opportunities to actively engage with popular, social and digital media in order to shift discourses and expand societal understanding of a given issue, whether energy related or otherwise (Lowan-Trudeau, 2019, 2021; Milstein et al., 2017). For example, educators in a range of K-12, post-secondary or community contexts can facilitate energy-related critical media literacy exercises that prompt learners to consider the subtle or overt influences of a publisher, author or funder on a given media artefact (e.g., print, digital text, audiovisual) in seeking to identify implicit, explicit or null/missing (Eisner, 2002) messages and associated discourses therein.

\section{Critically considering gender dynamics}

Awareness and attention to gender dynamics is also germane to critical energy literacy. As noted by Maina-Okori et al. (2018), intersectional approaches that consider gender alongside other sociocultural factors such as age, ability, culture, language and ethnicity must be part of contemporary environmental education initiatives. A critical gender perspective leads us to question who is benefitting from a particular project or technology as well as who is leading, oppressing others or being oppressed themselves? Such an approach may also assist us in identifying and exploring gender roles and dynamics in various energy industries, developments and educational organisations - considering who is or isn't assuming occupational or leadership roles (Pearl-Martinez \& Stephens, 2016). For example, while keeping in mind historical and ongoing patriarchal dynamics within environmental activist and education contexts (Breunig \& Russell, 2020) and the disproportionate impacts of climate change upon women globally (Gough \& Whitehouse, 2020), an increasingly notable number of community-based environmental organisations are led by women (Kaplan, 2019; Taylor, 2014). This dynamic is also reflected in the Youth Strikes for Climate movement which, as previously noted, was initiated by Greta Thunberg with many other young women taking the lead on regional initiatives (Kaplan, 2019).

In the following section, we consider renewable energy development and education in the context of the Canadian province of Alberta as an illuminating exemplar of critical energy literacy.

\section{Renewable Energy in Alberta, Canada}

Amid growing concern regarding climate change, environmental degradation from nonrenewable energy sources and fluctuating resource markets, renewable energy development has rapidly expanded across Canada and around the world - solar panels, windmills, geothermal wells and small-scale run-of-river hydroelectric generators have increasingly appeared across the Canadian landscape. Larger scale renewable energy projects by private corporations and governments typically replace non-renewable energy sources such as oil, gas and coal, but may not result in ostensibly noticeable effects upon the target population's environmental awareness and energy use; for example, in Calgary - a city of approximately 1.3 million people in southern Alberta - many people may be completely unaware that their light rail transit (LRT) system, the CTrain, is entirely powered by energy drawn from large windmill installations in rural areas south of the city (Grieco, 2015). In contrast, smaller scale projects are typically intended to directly serve the needs of those in the immediately surrounding area while also providing increased economic, environmental and in the case of Indigenous communities, political sovereignty rooted in traditional environmental values and local geographical, meteorological and ecological knowledge (Bargh, 2010, 2012; Henderson, 2013; Hoicka \& McArthur, 2018; Lipp et al., 2016). Given immediately visible changes to the surrounding landscape and infrastructure, community members are commonly more aware of such initiatives. 
An emerging group of educators in a range of community, school and post-secondary contexts in Alberta and beyond are attempting to respond to such trends by providing students with both technically and critically informed information related to renewable energy through a variety of pedagogical strategies (Henderson, 2014; Jennings, 2009; Jennings \& Lund, 2001; Liarakou et al., 2009). Although some educators must rely upon theoretical information, classroom-friendly micro models, and examples of projects in relatively distant locales, an increasing number of K-12 schools, postsecondary institutions, non-profit organisations and Indigenous communities are developing in situ renewable energy installations which both serve their electrical needs and provide experiential, place-based teaching and learning opportunities for educators and students alike.

For example, 36 schools in Alberta benefited from a funding initiative by the previous New Democratic Party (NDP) government to install solar panels and other renewable energy technologies on their roofs and surrounding grounds (Government of Alberta, 2016). Installations of this nature provide experiential learning opportunities for educators and students. For instance, some schools have ensured that digital readings from the solar panels or similar are prominently displayed so that students can observe the energy produced in real time (Max, 2018). The long-term benefits of schools offsetting not only environmental but also economic costs through such installations are also being recognised by communities such as Wetaskiwin in central Alberta (Max, 2018). Taken together, these dynamics provide strong opportunities for educators to engage their students in technically as well as critically oriented activities and discussions. As such, in situ installations offer a wide array of learning opportunities.

Elsewhere, T'Souke First Nation on Vancouver Island in neighbouring British Columbia is a recognised leader in community-based renewable energy development; extensive solar panel installations have allowed the community to gain increased energy, economic and environmental sovereignty while creating in situ renewable energy-related learning and training opportunities for youth and other community members that support, reflect and extend the community's traditional environmental values (CBC News 2020; Kimmett, 2009; Ozog, 2012). T'Souke First Nation's successes have inspired Indigenous and non-Indigenous communities and governments across British Columbia (Ozog, 2012) and the rest of Canada with similar projects arising more recently in Alberta through a now defunct funding initiative that was also introduced by the previous NDP government (Government of Alberta, 2018; Wilt, 2018).

Despite such promising developments, the combined social, political, ecological and technical aspects of renewable energy development (Jaffar, 2015) present significant challenges for interested educators who may be grounded in one relevant disciplinary area, but not another (Henderson, 2014; Kandpal \& Broman, 2014; Liarakou et al., 2009). For example, while a science educator may be familiar with the technical and ecological aspects of solar, wind or geothermal power, they might struggle with social or political considerations such as government policies regulating whether or not individuals or communities can be reimbursed for excess power generated by their installation that is directed back into the electrical grid - a process commonly known as feed-in-tariffing (FIT) or reverse metering (Stokes, 2013). Conversely, social science educators may be interested and well versed in the sociopolitical aspects of renewable energy initiatives but lacking in technical or environmental expertise.

In consideration of the Truth and Reconciliation Commission's Calls to Action (2015) and other educational mandates such as the Association of Canadian Deans of Education Accord on Indigenous Education (2010) and Alberta's new Teaching Quality Standards (2018) which emphasise Indigenous perspectives, educators might also be interested in exploring the recent rise of renewable energy developments by Indigenous communities across Canada (Henderson, 2013; Krupa et al., 2015; Laboucan-Massimo, 2017; Lowan-Trudeau, 2019; Ozog, 2012) with their students. However, as documented by Greg's research in this area (Lowan-Trudeau, 2019), such educators may find themselves lacking in relevant cultural awareness and an adequate understanding of associated Indigenous political, economic, land and environmental rights. 
Cultural, political and geographical contexts are key considerations for renewable energy educators. For example, the province of Alberta provides a particularly interesting base from which to conduct this inquiry. Geographically, in arguable contrast to its reputation as a centre of oil and gas development, Alberta is recognised as a region well suited to renewable energy development due to its natural abundance of wind, sunshine and rivers descending from the Rocky Mountains (Kralovic \& Mutysheva, 2006). Politically, amidst a shift from the longstanding rule of the Progressive Conservative Party to the NDP in 2015, and subsequent return to a conservative government in 2019, support for non-renewable energy sources was maintained. However, similar to the federal (Government of Canada, 2015) and other provincial governments (Province of British Columbia 2015; Independent Energy System Operator, 2018), Alberta's NDP government established significant funds to support the previously mentioned renewable energy initiatives by Indigenous communities (Government of Alberta, 2018; Wilt, 2018) and solar power installations on 36 public school sites (Government of Alberta, 2016). This is especially notable due to the recent crash in oil prices that resulted in widespread job losses in Alberta along with a desire on the part of many in the oil and gas industry to refocus their skills in more sustainable fields (McGarvey, 2017). Such trends may also introduce opportunities for assessing and addressing gender diversity, or lack thereof, in Alberta's energy industries (Pearl-Martinez \& Stephens, 2016).

Youth in Alberta have also been proactive in building societal critical energy literacy through climate and renewable energy-related advocacy and activism. For example, Student Energy was formed in Calgary in 2009 by a trio of students at Mount Royal University (studentenergy.org). It has since expanded to include chapters across Canada and internationally with a consistent focus on climate and energy justice.

Despite or perhaps due to the aforementioned political changes, socio-economic trends and geographical positioning, environmental education scholars Jickling (2003) and Niblett (2008) might suggest that critical energy educators in Alberta must remain prepared to address lingering tensions between those supportive of conventional energy and those more interested in renewables. With the shift back to a conservative government in 2019, this is a particularly interesting time to consider such dynamics.

It is also important to acknowledge that renewable energy developments are not problem-free solutions that will solve all of the planet's climate, pollution and socio-economic injustice woes without certain impacts. A range of interconnected social, economic, political, technical, health and ecological challenges have also arisen (Bargh, 2010; Richards, Noble \& Belcher, 2012; Stokes, 2013) along with debates regarding, for example, the impact of large windmills on birds and human health (Liarakou et al., 2009; van der Horst, 2007; Walker \& Christidis, 2018). Some might also advocate for both pursuing renewable energy development and reducing general energy dependency as the best way forward (Lowan-Trudeau, 2019).

The grassroots efforts of individuals and smaller community groups in a variety of geographic and economic contexts must also be considered in relation to varying regional, provincial and federal policies guiding or impeding renewable energy development and implementation (Hoicka and McArthur, 2018). Compounding the aforementioned challenges is the fact that critical renewable energy education is a distinctly underexplored area of both research and practice (Jennings, 2009), leaving educators with limited guidance, technical training and networking opportunities. As such, it is a key area that may be better understood if approached through a lens of critical energy literacy.

\section{Conclusion}

Developed through consideration of the dynamics presented throughout this article both related to and extending beyond the Youth Strike for Climate, we proposed critical energy literacy as an emerging theory that denotes understanding of the social, environmental, political and economic 
challenges, benefits and impacts of various energy sources, developments and technologies. Our discussion of critical energy literacy was further grounded in critical and decolonising approaches to STEM education; considerations for collaborative multi-, inter- and transdisciplinary pedagogy; critical place-based inquiry and pedagogy; critical gender perspectives and critical media literacy and engagement. Enhancing societal critical energy literacy will assist with more equitable energy, transit, construction and environmental planning by and for communities, businesses and governments. In this article, we shared insights related to and principles for critical energy literacy based on recent reviews of literature as well as $\mathrm{K}-12$, post-secondary and not-for-profit curricula in Canada with consideration for Indigenous, non-Indigenous and international contexts. Our discussion of energy development, education and critical energy literacy focused on the socioenvironmentally complex Canadian province of Alberta as an illuminating exemplar.

The Youth Strike for Climate brought important sustained attention to issues of energy and environmental justice across Canada and around the world. As educational scholars, we must recognise, make space for and seek opportunities to support, collaborate with and learn from youth who are continuing with this important work through advocacy, activism and education. We continue to refine our emerging theory of critical energy literacy and related considerations through ongoing interviews with critical energy educators across Canada; future research that engages more directly with youth perspectives on and experiences with developing critical energy literacy would also prove insightful. We look forward to further opportunities for scholarship and practice.

\section{Note}

1 Also called the School Strike for Climate, Fridays for Future, and Skolstrejk för klimatet, among other terms (Verlie \& Flynn, 2020).

Acknowledgements. none

Financial Support. This work was supported by a Social Sciences and Humanities Research Council (SSHRC) of Canada Insight Grant (\#435-2019-0238).

\section{References}

Agyeman, J. (2008). Toward a 'just'sustainability? Continuum, 22, 751-756.

Aikenhead, G.S., \& Ogawa, M. (2007). Indigenous knowledge and science revisited. Cultural Studies of Science Education, 2 , 539-620.

Alberta Education. (2018). Teaching quality standard. Retrieved September 12, 2018 from https://education.alberta.ca/media/ 3739620/standardsdoc-tqs-_fa-web-2018-01-17.pdf

Anfara, V.A., \& Mertz, N.T. (Eds.) (2006). Theoretical frameworks in qualitative research. Thousand Oaks, CA: Sage.

Association of Canadian Deans of Education. (2010). Accord on Indigenous education. Retrieved September 26, 2018 from http://csse-scee.ca/acde/wp-content/uploads/sites/7/2017/08/Accord-on-Indigenous-Education.pdf

Awasis, S. (2014). Pipelines and resistance across Turtle Island. In T. Black, S. D’Arcy, T. Weis, \& J. Kahn Russell (Eds.) A line in the Tar Sands (pp. 253-266). Toronto: Between the Lines.

Bang, M., \& Medin, D. (2010). Cultural processes in science education: Supporting the navigation of multiple epistemologies. Science Education, 94, 1008-1026.

Bargh, M. (2010). Indigenous peoples' energy projects. Australasian Canadian Studies Journal, 28, 1-30. Retrieved from http://papers.ssrn.com/sol3/papers.cfm?abstract_id=1939505

Bargh, M. (2012). Rethinking and re-shaping indigenous economies: Māori geothermal energy enterprises. Journal of Enterprising Communities: People and Places in the Global Economy, 6, 271-283. https://doi.org/10.1108/ 17506201211258423

Barnhardt, R., \& Kawagley, A.O. (2005). Indigenous knowledge systems and Alaska Native ways of knowing. Anthropology and Education Quarterly, 36, 8-23.

BC First Nation Unveils Solar Power Project. (2009, July 17). CBC News. https://www.cbc.ca/news/canada/british-columbia/ b-c-first-nation-unveils-solar-power-project-1.780255

Bernstein, J.H. (2015). Transdisciplinarity: A review of its origins, development, and current issues. Journal of Research Practice, 11, 1-20.

Bowers, C.A. (2008). Why a critical pedagogy of place is an oxymoron. Environmental Education Research, 14, 325-335. 
Brady, M.J., \& Monani, S. (2012). Wind power! Marketing renewable energy on tribal lands and the struggle for just sustainability. Local Environment, 17, 147-166. https://doi.org/10.1080/13549839.2011.646966

Breunig, M., \& Russell, C. (2020). Long-term impacts of two secondary school environmental studies programs on environmental behaviour: The shadows of patriarchy and neoliberalism. Environmental Education Research, 26, 701-715.

Bullock, E.C. (2017). Only STEM can save us? Examining race, place, and STEM education as property. Educational Studies, $53,628-641$.

Carrington, K., McIntosh, A., Scott, J. (2010). Globalization, frontier masculinities and violence: Booze, blokes and brawls. British Journal of Criminology, 50, 393-413.

CBC News. (2020, February 27). 'This shows we are winning': Greta Thunberg responds after sexually graphic illustration surfaces on Facebook. CBC News. https://www.cbc.ca/news/canada/edmonton/greta-thunberg-xsite-energy-sexual-image1.5478561

Choi, B.C.K., \& Pak, A.W.P. (2006). Multidisciplinarity, interdisciplinarity and transdisciplinarity in health research, services, education and policy: 1. Definitions, objectives, and evidence of effectiveness. Clinical and Investigative Medicine. Medecine Clinique Et Experimentale, 29, 351-364.

de Freitas, E., Lupinacci, J., \& Pais, A. (2017). Science and technology studies $\times$ educational studies: Critical and creative perspectives on the future of STEM education. Educational Studies, 53, 551-559. https://doi.org/10.1080/00131946.2017. 1384730

Delgado, E. (2016). Energy geographies: Thinking critically about energy issues in the classroom. Journal of Geography in Higher Education, 40, 39-54. https://doi.org/10.1080/03098265.2015.1089475

DeWaters, J.E., \& Powers, S.E. (2011). Energy literacy of secondary students in New York State (USA): A measure of knowledge, affect, and behavior. Energy Policy, 39, 1699-1710.

Eisner, E. (2002). Educational imagination: On the design and evaluation of school programs. Hoboken: Merrill Prentice Hall.

Gough, A., \& Whitehouse, H. (2020). Challenging amnesias: Re-collecting feminist new materialism/ecofeminism/climate/ education. Environmental Education Research, 26, 1420-1434.

Government of Alberta. (2016). Solar panels to be featured in Alberta's new schools. Retrieved July 31, 2018 from https://www. alberta.ca/release.cfm?xID=436961ac661cd-df8f-5721-666c7b634e826188

Government of Alberta. (2018). Alberta Indigenous green energy program. Retrieved July 31, 2018 from http://indigenous. alberta.ca/AIGEDP.cfm

Government of Canada. (2015). ecoEnergy for Aboriginal and northern communities program. Retrieved June 1, 2015 from https://www.aadncaandc.gc.ca/eng/1100100034258/1100100034259

Greenwood, D.A. (2008). A critical pedagogy of place: From gridlock to parallax. Environmental Education Research, 14, 336-348.

Grieco, M. (2015). Poverty mapping and sustainable transport: A neglected dimension. Research in Transportation Economics, $51,3-9$.

Gruenewald, D.A. (2003). The best of both worlds: A critical pedagogy of place. Educational Researcher, 32, 3-12.

Henderson, C. (2013). Aboriginal power: Clean energy and the future of Canada's First Peoples. Erin, ON: Rainforest Editions.

Henderson, M. (2014). Solar-powered learning: Educating for an ecological literacy. In F. Deer, T. Falkenberg, B. McMillan, \& L. Sims (Eds.) Sustainable well-being: Concepts, issues, and educational practices (pp. 95-104). Winnipeg, MB: ESWB Press.

Hodges, H.E., \& Stocking, G. (2016). A pipeline of tweets: Environmental movements' use of Twitter in response to the Keystone XL pipeline. Environmental Politics, 25, 223-247.

Hoicka, C.E., \& MacArthur, J.L. (2018). From tip to toes: Mapping community energy models in Canada and New Zealand. Energy Policy, 121, 162-174.

Independent Energy System Operator. (2018). Indigenous communities in Ontario's energy sector. Retrieved September 12, 2018 from http://www.ieso.ca/get-involved/indigenous-relations/overview

Jaffar, A. (2015). Establishing a clean economy or strengthening Indigenous sovereignty: Conflicting \& complementary narratives for energy transitions. Unpublished Master's Thesis, University of Guelph, Canada.

Jennings, P. (2009). New directions in renewable energy education. Renewable Energy, 34, 435-439.

Jennings, P., \& Lund, C. (2001). Renewable energy education for sustainable development. Renewable Energy, 22, 113-118.

Jickling, B. (2003). Environmental education and advocacy: Revisited. The Journal of Environmental Education, 34, $20-27$.

Kandpal, T.C., \& Broman, L. (2014). Renewable energy education: A global status review. Renewable and Sustainable Energy Reviews, 34, 300-324.

Kaplan, S. (2019, September 24). Teen girls are leading the climate strikes and helping change the face of environmentalism. The Washington Post. https://www.washingtonpost.com/science/2019/09/24/teen-girls-are-leading-climate-strikeshelping-change-face-environmentalism/

Katz-Rosene, R.M. (2017). From narrative of promise to rhetoric of sustainability: A genealogy of oil sands. Environmental Communication, 11, 401-414. https://doi.org/10.1080/17524032.2016.1253597

Kellner, D., \& Share, J. (2007). Critical media literacy, democracy, and the reconstruction of education. In S. Steinberg \& D. Macedo (Eds.) Media literacy: A reader (pp. 3-23.). New York: Peter Lang. 
Kimmett, C. (2009, 24 July). First Nation takes lead on solar power. The Tyee.ca. http://thetyee.ca/News/2009/07/24/ FirstNationSolarPower/

Kralovic, P., \& Mutysheva, D. (2006). The role of renewable energy in Alberta's energy future. Calgary, AB: Alberta Energy Futures Project, Institute for Sustainable Energy and Economy, University of Calgary.

Krupa, J., Galbraith, L., \& Burch, S. (2015). Participatory and multi-level governance: Applications to Aboriginal renewable energy projects. Local Environment, 20, 81-101. https://doi.org/10.1080/13549839.2013.818956

Laboucan Massimo, M. (2017). Chapter 7: From our homelands to the tar sands. In D. Christian \& R. Wong (Eds.) Downstream: Reimagining water (pp. 81-88). Waterloo, ON: Wilfred Laurier Press.

LaDuke, W. (2014). Ending the age of fossil fuels and building an economics for the Seventh Generation. In T. Black, S. D'Arcy, T. Weis, J. Kahn Russell (Eds.) A line in the Tar Sands (pp. 229-239). Toronto, ON: Between the Lines.

Liarakou, G., Gavrilakis, C., \& Flouri, E. (2009). Secondary school teachers' knowledge and attitudes towards renewable energy sources. Journal of Science Education and Technology, 18, 120-129.

Lipp, J., Tarhan, M.D., \& Dixon, A. (2016). Accelerating renewable energy cooperatives in Canada: A review of experiences and lessons. Toronto, ON: TREC Renewable Energy Co-Operative.

Lowan-Trudeau, G. (2015). From bricolage to métissage: (Re)thinking intercultural approaches to Indigenous environmental education and research. Peter Lang. [Volume \#8 in (Re)thinking Environmental Education, C. Russell \& J. Dillon (Series Eds.)].

Lowan-Trudeau, G. (2017). Indigenous environmental education: The case of renewable energy projects. Educational Studies: A Journal of the American Educational Studies Association, 53, 601-613.

Lowan-Trudeau, G. (2019). Protest as pedagogy: Teaching, learning, and Indigenous environmental movements. Peter Lang. [Volume \#13 in (Re)thinking Environmental Education, C. Russell \& J. Dillon (Series Eds.)].

Lowan-Trudeau, G. (2021). Indigenous environmental media coverage in Canada and the United States: A comparative critical discourse analysis. Journal of Environmental Education, 52, 83-97. DOI: 10.1080/00958964.2020.1852525

Lowan-Trudeau, G., \& Fowler, T.A. (in press). Considering Indigenous environmental issues in Canadian curricula: A critical discourse analysis. Journal of the Canadian Association for Curriculum Studies.

Lucchesi, A.H. (2019). Mapping geographies of Canadian colonial occupation: Pathway analysis of murdered Indigenous women and girls. Gender, Place \& Culture, 26, 868-887. DOI: 10.1080/0966369X.2018.1553864

Maina-Okori, N.M., Koushik, J.R., \& Wilson, A. (2018). Reimagining intersectionality in environmental and sustainability education: A critical literature review. The Journal of Environmental Education, 49, 286-296.

Martins, A., Madaleno, M., \& Dias, M.F. (2020). Energy literacy: What is out there to know? Energy Reports, 6, 454-459.

Max, C. (2018). Using the sun to power WRPS schools. The Wetaskiwin Times. https://www.wetaskiwintimes.com/news/ local-news/using-the-sun-to-power-wrps-schools

McGarvey, D. (2017, November 3). Renewable energy jobs provide new opportunities for Alberta workers. CBC News. Retrieved July 31, 2018 from https://www.cbc.ca/news/canada/calgary/alberta-renewables-wind-solar-jobs-energy-1. 4385124

Milstein, T., Pileggi, M., \& Morgan, E.L. (Eds.). (2017). Environmental communication pedagogy and practice. New York: Routledge.

Newell, P., \& Mulvaney, D. (2013). The political economy of the 'just transition'. The Geographical Journal, 179, 132-140.

Niblett, B. (2008). Appreciative resistance: Balancing activism and respect. Pathways: The Ontario Journal of Outdoor Education, 20, 4-7.

Ozog, S. (2012). Towards First Nations energy self-sufficiency: Analyzing the renewable energy partnership between Tsou-ke Nation and Skidegate Band. Unpublished master's thesis, University of Northern British Columbia, Prince George, BC.

Pearl-Martinez, R., \& Stephens, J.C. (2016). Toward a gender diverse workforce in the renewable energy transition. Sustainability: Science, Practice and Policy, 12, 8-15.

Pellow, D.N. (2017). What is critical environmental justice? Hoboken: John Wiley \& Sons.

Province of British Columbia. (2015). First Nations clean energy business fund. Retrieved June 1, 2015 from http:// www2.gov.bc.ca/gov/content/environment/natural-resource-stewardship/consulting-with-first-nations/first-nationsclean-energy-business-fund

Reid, C., Greaves, L., \& Kirby, S.L. (2017). Experience, research, social change: Critical methods (3rd Ed.). Toronto: U of T Press.

Richards, G., Noble, B., \& Belcher, K. (2012). Barriers to renewable energy development: A case study of large-scale wind energy in Saskatchewan, Canada. Energy Policy, 42, 691-698.

Robertson, L., \& Scheidler-Benns, J. (2016). Critical media literacy as a transformative pedagogy. Literacy Information and Computer Education Journal, 7, 2247-2253.

Scully, A. (2012). Decolonization, reinhabitation and reconciliation: Aboriginal and place-based education. Canadian Journal of Environmental Education (CJEE), 17, 148-158.

Stevenson, R.B. (2008). A critical pedagogy of place and the critical place(s) of pedagogy. Environmental Education Research, $14,353-360$. 
Stokes, L.C. (2013). The politics of renewable energy policies: The case of feed-in tariffs in Ontario, Canada. Energy Policy, 56, 490-500.

Takahashi, B., \& Rosenthal, S. (Eds.). (2018). Environmental communication among minority populations. New York: Routledge.

Taylor, D.E. (2014). The state of diversity in environmental organizations. Green 2.0. http://www.diversegreen.org/thechallenge/

Truth and Reconciliation Canada. (2015). Honouring the truth, reconciling for the future: Summary of the final report of the Truth and Reconciliation Commission of Canada. Winnipeg: Truth and Reconciliation Commission of Canada.

Tuck, E., \& McKenzie, M. (2015). Relational validity and the 'where' of inquiry: Place and Land in qualitative research. Qualitative Inquiry, 21, 633-638.

U.S. Department of Energy. (2017). Energy literacy framework. Retrieved February 1, 2021 from https://www.energy.gov/ sites/prod/files/2017/07/f35/Energy_Literacy.pdf

van der Horst, D. (2007). NIMBY or not? Exploring the relevance of location and the politics of voiced opinions in renewable energy siting controversies. Energy Policy, 35, 2705-2714.

Verlie, B., \& Flynn, A. (2020). Call for papers: Special issue: Striking from school for the climate. Australian Journal of Environmental Education, 1-5. https://www.cambridge.org/core/services/aop-file-manager/file/5ee8bd8b190c0a44 38d7c67b/Striking-from-school-to-save-the-climate-CFP.pdf

Walker, C., \& Christidis, T. (2018). Activists against research: Experiences studying wind energy in Ontario. The Canadian Geographer, 62, 282-287.

Weber, B.A., Geigle, J., \& Barkdull, C. (2014). Rural North Dakota's oil boom and its impact on social services. Journal of Social Work, 59, 62-72.

Welsch, W. (1999). Transculturality- the puzzling form of cultures today. In Featherstone, M. \& Lash, S., (Eds.), Spaces of culture: City, nation, world (pp. 194-213). London: Sage.

Wilt, J. (2018). How solar power is helping redefine this Alberta First Nation. The Narwhal, Retrieved January 9, 2018 from https://thenarwhal.ca/how-solar-power-helping-redefine-alberta-first-nation/

Cite this article: Lowan-Trudeau, G., \& Fowler, T.A. (2022). Towards a theory of critical energy literacy: the Youth Strike for Climate, renewable energy and beyond. Australian Journal of Environmental Education 38, 58-68. https://doi.org/10.1017/ aee. 2021.15 